PAULINA PERET-DRĄŻEWSKA

Uniwersytet im. Adama Mickiewicza

w Poznaniu

\title{
WOLNOŚĆ WYBORU W KREOWANIU WŁASNEGO STYLU ŻYCIA PRZEZ WSPÓŁCZESNĄ MŁODZIEŻ
}

ABSTRACT. Peret-Drążewska Paulina, Wolność wyboru w kreowaniu własnego stylu życia przez wspótczesna młodzież [Freedom of Choice in Creation of Your Own Life Style of Modern Youth]. Studia Edukacyjne nr 42, 2016, Poznań 2016, pp. 191-203. Adam Mickiewicz University Press. ISSN 1233-6688. DOI: $10.14746 /$ se.2016.42.11

This article is dedicated to reflection on the lifestyle of contemporary young people, which is formed on the basis of freedom of choice. This is due to the specific nature of the globalized reality of sociocultural, in particular popular culture and consumerism, which are the main element of youth lifestyle emphasizing the role of unlimited possibilities in shaping their own identity and way of life of the elements that once were dependent mainly on class membership.

Key words: lifestyle, youth, modernity, choice

\section{Wprowadzenie}

Rzeczywistość społeczno-kulturowa pozostaje areną permanentnych przemian dokonujących się na podłożu idei globalizacyjnych, które mają bezpośredni wpływ na jakość przeżywania codzienności przez jednostki egzystujące we współczesności. Postęp technologiczny, wpływ mass mediów, kultura konsumpcyjna, seksualizacja, orientacja na zmianę i wiele innych trendów ponowoczesności sprawiły, iż przekształcił się rys preferowanego stylu życia, co wymaga podjęcia ponownych analiz w ramach dyskursu na temat stylów życia w obecnych warunkach ponowoczesności, które nie pozostają bez znaczenia dla funkcjonowania jednostek i grup społecznych. 
Współczesne warunki społeczno-kulturowe podlegające permanentnym przemianom, pozostające $\mathrm{w}$ procesie dookreślenia własnych ram definicyjnych, znacząco utrudniają sprecyzowanie istoty stylu życia jednostek egzystujących w niejednorodnej rzeczywistości. Preferowany we współczesności styl życia znajduje się ciągle na etapie konstytuowania, a co za tym idzie jest zmienny, niejednorodny, trudny do przedstawienia jako jedna zwarta całość. Specyfika kategorii „styl życia” w czasach szybko zachodzących przeobrażeń socjokulturowych została opisana przez Elżbietę Tarkowską, która wyjaśnia, iż:

(...) styl życia należałoby zaliczyć do kategorii badawczych rodem z „socjologii okresu stabilizacji”, niezbyt odpowiednich do chwytania szybko zachodzących zmian, sprawdzających się natomiast w badaniu zjawisk „długiego trwania1.

Zatem, można stwierdzić, iż wyjaśnienie obecnie zachodzących przemian stylu życia stanowi wyzwanie, które wymaga podjęcia analiz oraz ujmowania niniejszej kategorii w kontekście kondycji współczesnego społeczeństwa.

Realia egzystencji znamionują codzienną rzeczywistość, zatem niejako kształtują preferowane style życia. Niniejszą zależność podkreśliła Mirosława Marody pisząc, iż:

jest zatem styl życia - o czym czasami się zapomina - pojęciem nierozerwalnie złączonym $z$ rozwojem nowoczesnego społeczeństwa. Nie tylko ze względu na to, iż jednym $z$ jego elementów definicyjnych jest istnienie relatywnej swobody wyboru przez jednostki działań lokujących je w przestrzeni społecznej, a tym samym narzucających obserwatorowi ich identyfikację społeczną².

Swoboda wyboru stanowi prymarną cechę ponowoczesnego społeczeństwa charakteryzującego się relatywnością ujęć, wielością możliwości, jak również koniecznością autokreacji. Warunki społeczno-kulturowe tego typu sprawiają, iż termin „styl życia” znacznie wykracza poza sztywne ramy związane z klasycznym ujęciem socjologicznym, które postrzega styl życia jako kategorię dyferencjacji społecznej, wyznacznik pozycji społecznej oraz przynależności do danej grupy. Klasyczną tego typu teorią jest koncepcja Pierra Bourdieu³ ${ }^{3}$ która opiera się na klasyfikacji stylów życia na podstawie

${ }^{1}$ E. Tarkowska, Czas w życiu Polaków, Warszawa 1992, s. 31-32.

2 M. Marody, Styl życia jako kategoria opisu socjologicznego, [w:] Wartości, praca, zakupy... O stylach życia Polaków, red. M. Falkowska, Warszawa 1997, s. 9.

3 Patrz: P. Bourdieu, Dystynkcja. Społeczna krytyka władzy sadzenia, przekł. P. Biłos, Warszawa 2005; P. Bourdieu, J-C. Passeron, Reprodukcja. Elementy teorii systemu nauczania, przekł. E. Neyman, Warszawa 2006. 
odrębności wobec innych stylów preferowanych przez różnorodne klasy społeczne. Również Thorsten Veblen ${ }^{4}$ oraz Max Weber ${ }^{5}$ ujmowali styl życia jako efekt ukazywania odrębności międzygrupowych czy międzyklasowych, co wiąże się ze znaczącą rolą przynależności społecznej jako czynnika konstytuującego preferowane style życia.

Jak wyjaśnia Zbyszko Melosik,

w przeszłości miejsce różnych grup ludzi (czy różnych klas) w strukturze społecznej było jasno odróżnialne - na podstawie pochodzenia (urodzenia), poziomu życia i wykształcenia, pełnionych funkcji i ról zawodowych. Współcześnie (...) przynależność klasowa traci na znaczeniu, a główną płaszczyzną różnego typu klasyfikacji i zróżnicowań społecznych staje się styl życia. Żyjemy w coraz większym stopniu poprzez tymczasowe grupy zainteresowań i wspólnego spędzania wolnego czasu, grupy "life stylowe" 6 .

Współcześnie zwiększyła się rola jednostki jako kreatora własnych losów oraz kształtowanego stylu życia. Wynika to z faktu, iż obecna rzeczywistość socjokulturowa dostarcza ludziom szerokiego wachlarza możliwości, dzięki czemu istotnego znaczenia nabiera pojęcie wolności wyboru, które zajęło miejsce przynależności społecznej jako wyznacznika pozycji społecznej. W związku z tym konieczna wydaje się ponowna analiza istoty stylu życia, który stanowi pokłosie jednostkowych preferencji, indywidualnych decyzji, poglądów, wartości.

\section{Wolność wyboru \\ jako wyznacznik kreowania stylu życia we współczesności}

Wolność wyboru to jedna z podstawowych cech ponowoczesności, która niejako kształtuje pozostałe zasady funkcjonowania człowieka w obecnych realiach globalizacyjnych. To wolność wyboru determinuje nastawienie na karierę, indywidualizację, elastyczność, tendencję do permanentnej zmiany, relatywizm moralny, przeobrażenia $\mathrm{w}$ dziedzinie funkcjonowania współczesnych rodzin i wiele innych procesów, które łącznie tworzą ponowoczesny rys rzeczywistości społeczno-kulturowej. Niniejsze założenie stało się podstawą koncepcji homo eligens autorstwa Andrzeja Sicińskiego, który podkreślał, iż

${ }^{4}$ Patrz m.in.: T. Veblen, Teoria klasy próżniaczej, przekł. J.K. Zagórscy, Warszawa 1971.

5 Patrz m.in.: M. Weber, Szkice z socjologii religii, przekł. J. Prokupiuk, H. Wandowski, Warszawa 1984.

${ }^{6}$ Z. Melosik, Kultura popularna i tożsamość młodzieży. W niewoli władzy i wolności, Kraków 2013, s. 279. 
człowiek jest niesprowadzalny do sumy reakcji na uwarunkowania, bodźce, że przeciwnie - do jego „istoty” należy właśnie możliwość dokonywania wyborów, przekraczania własnych uwarunkowań7.

Homo eligens, czyli człowiek wybierający projektuje własny styl życia poprzez swobodny dobór różnorodnych, nawet przeciwstawnych idei oraz aktywności z szerokiej puli dostępnych, nieograniczonych możliwości. Hasło: „możesz być kim tylko zechcesz” stało się współcześnie podstawą rozważań na temat kształtowania tożsamości czy kreacji stylu życia, co pociąga za sobą konieczność ujmowania owych kategorii przez pryzmat wolności wyboru jako czynnika go konstytuującego.

Styl życia zatem to efekt wyboru oraz indywidualnej decyzji jednostek, które kreują siebie oraz swoją codzienność na podstawie własnych preferencji. Ich dobór niezależny jest od czynników zewnętrznych, tylko stanowi oryginalną całość ukształtowaną na podstawie wewnętrznych motywów jednostkowych, która skonstruowana jest z szeregu wielu różnorodnych elementów stylu życia.

Warto zauważyć, iż współczesna rzeczywistość społeczno-kulturowa cechuje się szeregiem dychotomii, sprzeczności, niejednoznaczności i wielokontekstowości, co dotyczy również analiz na temat ujęć stylów życia we współczesności. Jednym z nich jest rozumienie stylu życia jako efektu wolności wyboru jednostki; z kolei na przeciwległym biegunie leży koncepcja podkreślająca jedynie pozorną dowolność w podejmowaniu decyzji z szeregu narzuconych odgórnie propozycji, która de facto stanowi niewolę, ograniczenia i brak dowolności w projektowaniu własnego stylu życia. Niniejsza dwoistość stała się przedmiotem refleksji naukowej Zbyszko Melosika, który wyjaśnił, iż:

współczesny człowiek, oczywiście także młody, żyje jednocześnie w dwóch rzeczywistościach. Pierwsza z nich działa na podstawie zasady wolności jednostki w kreowaniu własnej biografii, tożsamości oraz niekończących się (pozornie?) swobodnych wyborów dokonywanych na płaszczyźnie kultury popularnej i konsumpcji. Druga rzeczywistość działa jak gdyby odwrotnie: jej logika opiera się na potężnych regulatorach tożsamości i życia społecznego ${ }^{8}$.

Również Zygmunt Bauman podkreślał ten fakt pisząc, iż:

niezależnie od stopnia wolności indywidualnych wyborów, sam nakaz dokonywania samodzielnych wyborów i uznawania każdego działania za skutek samodzielnego, swobodnego wyboru z całą pewnością nie jest już kwestią swobodnego wyboru ${ }^{9}$.

7 A. Siciński, Styl życia, kultura, wybór: szkice, Warszawa 2002, s. 81.

8 Z. Melosik, Kultura popularna i tożsamość młodzieży, s. 10.

9 Z. Bauman, Płynne życie, przekł. T. Kunz, Kraków 2007, s. 36-37. 
Wolność wyboru jako czynnik konstytuujący współczesne style życia stanowi równocześnie element wymagający dostosowania się jednostek do zaistniałych warunków, bowiem taki jest charakter aktualnych realiów społeczno-kulturowych. Ze względu na wiodący rys konstytuowania się stylów życia jako wyznaczników przynależności klasowej, wolność wyboru pozostaje kluczową kategorią, która określa aktualnie style życia we współczesności. Nie bez znaczenia jest rola czynnika wolicjonalnego oraz wartości wolności w procesie dokonywania znaczących planów życiowych oraz konstytuowania codzienności przez jednostki egzystujące $\mathrm{w}$ realiach płynnej nowoczesności. Fakt ten podkreśliła Lucyna Mac-Czarnik, która twierdzi, iż:

świadomość bycia sprawcą własnych czynów, podejmowanie odpowiedzialności za kształt własnego życia, zdolność do planowania i dokonywania ważnych decyzji stanowią szansę na ocalenie wolności jako istotnego wymiaru człowieczeństwa ${ }^{10}$.

Zatem, skoro wolność wyboru oraz poczucie sprawstwa stanowią tak istotną współcześnie wartość, to naturalnym tego efektem jest kreowanie stylu życia na podstawie własnych, nieograniczonych decyzji. Skutkiem tego jest również szeroka różnorodność preferowanych stylów życia, które stanowią wynik indywidualnych preferencji jednostkowych.

Współczesna rzeczywistość społeczno-kulturowa sprawiła, iż jednostka ma możliwość oraz zdolność kreowania własnej przestrzeni życiowej zgodnie z własnymi indywidualnymi preferencjami, a zatem ma moc sprawczą w określaniu swojego stylu życia. Co więcej, obecnie styl życia stał się kategorią, która w biegu życia jednostki może ulec nawet radykalnej zmianie. Zdolność do modyfikacji oraz dostosowania codzienności do zmieniających się warunków stały się podstawową kompetencją jednostek egzystujących $\mathrm{w}$ rzeczywistości permanentnej zmiany. W związku $\mathrm{z}$ tym nastąpiło duże zróżnicowanie stylów życia, stały się one wewnętrznie niespójne, niełatwa jest ich jednoznaczna klasyfikacja do określonego typu. Współcześnie kategoria styl życia przekształca się w hasło „style życia”, co ma na celu podkreślenie jej dynamiki, zmienności i niejednoznaczności.

Mając na uwadze atrybuty nowej jakości stylu życia we współczesnych warunkach społeczno-kulturowych, należy ukazać esencję niniejszych przemian, które uwidaczniają się w szczególności w zakresie stylów życia preferowanych przez młodzież, co uczynione zostanie $\mathrm{w}$ dalszej części artykułu.

10 L. Mac-Czarnik, Procesy poznawcze w planowaniu własnego życia u młodzieży, Rzeszów 2000, s. 9. 


\section{Młodzież jako grupa kreująca własny styl życia oparty na wolnym wyborze}

Młodzież w ujęciu socjologicznym rozumiana jest jako znacząca część systemu społecznego, która swoją energią, witalnością oraz odwagą wnosi do społeczeństwa ożywczy oraz prorozwojowy dynamizm. Hartmut M. Griese podkreślał, że:

młodość nie jest przede wszystkim fazą wiekową czy produktem natury, jak pokwitanie, lecz jest fenomenem społeczno-kulturowym, który w swoich przejawach podporządkowany jest czynnikom historyczno-społecznym ${ }^{11}$.

W związku z tym analiza na temat współczesnych stylów życia powinna opierać się na refleksji na temat funkcjonowania pokolenia młodych, jak również specyfiki obecnie panujących warunków społeczno-kulturowych.

Młodzi są grupą społeczną, której istotnym obszarem funkcjonowania stały się aktualne trendy globalizacyjne, zatem można określić, iż style życia współczesnej młodzieży stanowią znakomitą egzemplifikację ujmowania niniejszej kategorii jako odzwierciedlenia wolnych, nieograniczonych wyborów w zakresie projektowania kształtu własnego życia.

Cechy konstytutywne okresu adolescencji, takie jak młodzieńczy entuzjazm, optymizm, odwaga, skłonność do dokonywania zmian, poszukiwanie nowych rozwiązań, jak również zadania rozwojowe przynależne do tego etapu życia sprawiają, iż młodzi bacznie obserwują otaczającą rzeczywistość społeczno-kulturową, co skutkuje zdolnością dostrzegania i rozumienia obecnych, szybko zachodzących przemian. To młodzi wyjaśniają dorosłym meandry trendów współczesności, bowiem też niejako je kreują. Przykładem może być sfera nowoczesnych technologii informacyjnych, moda, konsumpcjonizm, mass media - to właśnie w tych istotnych obszarach aktywności jednostek w obecnie panujących warunkach globalizacyjnych młodzi stanowią grupę, dla której niniejsze wymiary stały się codziennym elementem ich funkcjonowania oraz autokreacji.

Obszary działalności życiowej człowieka zawierają się w wymiarze czasu wolnego, który obok konsumpcjonizmu określony został jako:

obszar, gdzie nie liczą się powinność czy obowiązek, lecz osobiste preferencje, przyjemność i wolny wybór - kategorie, z których kultura współczesna uczyniła podstawową potrzebę i wartość życiową ludzi. Można zaryzykować tezę, że w celu prowadzenia określonego stylu życia i zachowania pożądanego poziomu konsumpcji, dla

11 H.M. Griese, Socjologiczne teorie młodzieży. Wprowadzenie, przekł. J. Dąbrowski, Warszawa 1996, s. 19. 
przyjemności, których można doświadczać (zwłaszcza w czasie wolnym) młodzi ludzie inwestują $\mathrm{w}$ wykształcenie, karierę zawodową czy określone rozwiązania dotyczące życia prywatnego ${ }^{12}$

- wyjaśnia Krystyna Szafraniec. Zatem, współczesne pokolenie młodych jest szczególnie podatne na oddziaływania zglobalizowanych warunków społeczno-kulturowych, a więc niejako odzwierciedla społeczne tendencje przyszłych zmian. Wynika to między innymi z zakorzenienia młodzieży $\mathrm{w}$ kulturze popularnej, świecie wirtualnym, zjawisku konsumpcjonizmu, które to trendy kształtują rys codziennej egzystencji jednostek ponowoczesności.

Analiza stylów życia współczesnej młodzieży stanowi istotną podpowiedź na temat tego, jaki będzie kształt i kierunek rozwoju społeczeństw. Krystyna Szafraniec pisze, iż:

młodzież jest bardzo dobrym punktem odniesienia do obserwacji tego, co dzieje się z całym społeczeństwem. Jest soczewką, w której skupiają się najróżniejsze problemy i napięcia systemu. Jest barometrem zmian i społecznych nastrojów. Sytuacja młodych, ich sposób postrzegania świata, ich aspiracje i dążenia życiowe są miarą zmian, które już się dokonały, i dystansu, jaki jest jeszcze do pokonania13.

Styl życia pokolenia młodych ukazuje niejako obraz - widoczny efekt obserwacji aktualnych realiów społeczno-kulturowych, które młodzież trafnie interpretuje jako grupa wkraczająca w świat życia dorosłych.

Mając świadomość egzystencji w kulturze prefiguratywnej, która według koncepcji Margaret Mead ${ }^{14}$ podkreśla znaczenie pokolenia młodych jako swoistych przewodników po świecie współcześnie zachodzących przemian społeczno-kulturowych, należy z uwagą obserwować poczynania młodych w obszarze ich stylu życia, ponieważ stanowi to swoisty wskaźnik przyszłych, ogólnospołecznych trendów w tym zakresie.

Adolescencja to etap życia człowieka, kiedy głównym zadaniem rozwojowym jest kształtowanie własnej tożsamości. Niniejsze wyzwanie określenia własnego "ja” tożsamościowego jest szczególnie trudne w obecnej rzeczywistości socjokulturowej, ponieważ pozbawia ona jednostek poczucia bezpieczeństwa, pewności, stabilności - oparta jest na dychotomii, zmianie oraz ryzyku jako podstawowych wyznacznikach współczesności. W takich warunkach preferowany styl życia stanowi wynik wolnego wyboru jednostki, co jest również znaczącą składową procesu nadawania kształtu własnej

12 K. Szafraniec, Młodzi 2011, Warszawa 2011, s. 223.

13 Tamże, s. 11.

${ }^{14}$ Patrz: M. Mead, Kultura i tożsamość: studium dystansu międzypokoleniowego, przekł. J. Hołówka, Warszawa 2000. 
tożsamości. Anthony Giddens podkreślił, iż „rośnie znaczenie wyboru stylu życia w konstruowaniu własnej tożsamości i organizowaniu codziennej aktywności"15. W świetle niniejszej koncepcji, współczesna młodzież powinna być nastawiona na indywidualistyczne cele, osobiste preferencje, które stają się coraz mniej zależne od czynników zewnętrznych.

Proces indywidualizacji współczesnego społeczeństwa również nie pozostaje bez znaczenia dla procesu kształtowania własnej tożsamości. Sławomir Krzychała dokonując analizy projektów życia oraz kształtowania tożsamości w czasach indywidualizacji podkreślił, iż:

przemiany wywołane procesem indywidualizacji - zarówno w wymiarze strukturalno-społecznym, jak i biograficzno-indywidualnym - ogniskują się szczególnie w stylach życia oraz planach życiowych młodego pokolenia. Koncepcja tożsamości wymaga nowego odczytania i dookreślenia: wejście w społeczeństwo dorosłych nie jest tak istotne, jak indywidualna aranżacja własnego życia. Paradoksy (po?)nowoczesności dotykają samego rdzenia fazy młodości: tożsamość, ale jaka?; rodzina, ale jaka?; praca, ale jaka?; zaangażowanie społeczne, ale jakie?16.

Niniejsza teza stanowi esencję uwikłania młodzieży w specyfikę współczesnych warunków społeczno-kulturowych opartych na zmianie, jak również podkreśla rolę indywidualnej kreacji własnego stylu życia zgodnie z osobistymi preferencjami, które stają się coraz mniej zależne od zewnętrznych uwarunkowań środowiskowych.

\section{Popkultura oraz konsumpcjonizm jako znaczące elementy stylu życia współczesnej młodzieży}

Współczesne pokolenie młodych charakteryzujące się silnym przywiązaniem do obecnych trendów globalizacyjnych, które dotyczą w szczególności kultury popularnej oraz konsumpcjonizmu, stanowi znaczącą reprezentację aktualnie preferowanych stylów życia opartych na wolnym wyborze jako kryterium ich doboru. Warto zatem postrzegać młodzież jako grupę społeczną stanowiącą zwierciadło rozwoju współczesnego społeczeństwa, zwłaszcza że w obecnie panującym kulcie młodości, zjawisku nastolatyzacji

15 A. Giddens, Nowoczesność $i$ tożsamość. Ja i społeczeństwo w epoce późnej nowoczesności, przekł. A. Szulżycka, Warszawa 2006, s. 9.

16 S. Krzychała, Ryzyko własnego życia. Indywidualizacja w późnej nowoczesności, Wrocław 2007, s. 13-14. 
społeczeństwa ${ }^{17}$, to młodzi wyznaczają kierunek zachodzących przemian społeczno-kulturowych ${ }^{18}$.

Zasadność analizy dyskursu kultury popularnej wynika z jej podwójnego wiązania jednostek ze światem: przez jej pryzmat odbieramy rzeczywistość, która jest jednocześnie przez nią kreowana ${ }^{19}$. Kolejnym argumentem mówiącym o istotności niniejszego zagadnienia jest fakt, iż obecnie każda jednostka z krajów rozwiniętych bądź rozwijających się partycypuje $\mathrm{w}$ owej kulturze niezależnie od zajmowanego stanowiska (elit dominujących czy mas odbierających), bowiem elity nadające kształt popkulturze również stają się jej członkami i odbiorcami. Jedyną cechą różnicującą jest świadomość istnienia odmiennych form kulturowych ${ }^{20}$. Konieczność podejmowania prób zrozumienia zjawisk popkulturowych wynika również z faktu, iż wytwarzają one metakulturę, czyli „kulturę, która mówi o innej kulturze i nieustannie wytwarza warunki ku temu, aby komentować i projektować kolejne poziomy własnej ekspansji"21.

Głównymi założeniami kultury popularnej, będącymi znacznikiem nadającym jej kształt jest prymat przyjemności, rozumianej jako uzyskiwanie przez wszystkich osobistej satysfakcji z przekazu kulturowego niezależnie od zróżnicowań indywidualnych, ponieważ konstrukcja przekazu jest wieloznaczna i uniwersalna. Kolejną kategorią popkultury jest kontrola interpretowana jako umiejętność podejmowania decyzji, kierowania i panowania nad biegiem wydarzeń życiowych. Jest to dość trudne zadanie $\mathrm{z}$ uwagi na rozbieżność między wymogiem sprawowania kontroli a współczesnymi warunkami społecznymi ku temu, które uniemożliwiają wywiązanie się z tego obowiązku współczesności²2.

Konsumpcjonizm opiera się na ciągłym, nieprzerwanym wytwarzaniu potrzeb konsumenckich (głównie przez media), których stopień realizacji świadczy o pozycji społecznej jednostek. Zaspokojenie tych potrzeb jest podstawą autokreacji, które pozwala oddać się iluzji określania siebie jako indywidualności oraz członka grup społecznych zarazem.

17 W. Wrzesień, Europejscy poszukiwacze. Impresja na temat wspótczesnego pokolenia polskiej młodzieży, Warszawa 2009.

18 Zawarte w niniejszej części artykułu rozważania teoretyczne stanowią fragment rozprawy doktorskiej zatytułowanej: Obraz wspótczesnej młodzieży postrzegany z perspektywy rówieśników, napisanej przez autorkę pod kierunkiem prof. zw. dr hab. Agnieszki CybalMichalskiej. Skrócona jej wersja została opublikowana w: P. Peret-Drążewska, Wspótczesna młodzież postrzegana z perspektywy rówieśników. Studium teoretyczno-empiryczne, Poznań 2014.

${ }^{19}$ M. Krajewski, Kultury kultury popularnej, Poznań 2003, s. 7.

20 Tamże, s. 21.

21 W.J. Burszta, W. Kuligowski, Sequel. Dalsze przygody kultury w globalnym świecie, Warszawa 2005, s. 17.

${ }^{22}$ M. Krajewski, Kultury kultury popularnej, s. 35-43 i 95-105. 
W świecie płynnej nowoczesności potrzeby wyznaczające kierunek ludzkich działań „dojrzały” do miana pragnień. Jak tłumaczy Z. Bauman, jest to

byt znacznie bardziej od potrzeb ulotny i efemeryczny, nieuchwytny, kapryśny i zasadniczo nie odnoszący się do niczego w szczególności; samorodny i samowystarczalny motyw, który nie potrzebuje uzasadnienia ani przyczyny ${ }^{23}$.

Pragnienia, których immanentną cechą jest nietrwałość oraz zmienność doskonale wpisują się w płynnonowoczesną rzeczywistość społeczną, dlatego też stanowią przyczynę nadania teraźniejszości konsumpcyjnego kształtu, co określone jest mianem społeczeństwa konsumpcyjnego.

Kultura popularna oraz konsumpcjonizm jako wiodące trendy zglobalizowanej rzeczywistości nie pozostają bez znaczenia dla procesu konstruowania tożsamości przez współczesnych adolescentów, jak również dla preferencji związanych ze sposobem kreacji własnego stylu życia. Elementy stylu życia współczesnego pokolenia młodych oparte są w szczególności na zasadach promowanych przez współczesną kulturę konsumpcyjną, a zatem istotne są: przyjemność, ekstremalne doznania, natychmiastowość, nastawienie na teraźniejszość oraz konieczność szybkiej zmiany, elastyczność, czego następstwem jest kształtowanie tożsamości młodych również na takich zasadach. Jak pisze Zbyszko Melosik:

prymat natychmiastowości i zmiany prowadzi do znaczących przekształceń w stylu życia współczesnych społeczeństw, i w tożsamości młodzieży. Powstają styl życia typu instant i tożsamość instant, płynna i niestabilna pop tożsamość24.

Owa płynność oraz niestabilność znamionują posiadanie niemalże nieograniczonych możliwości nadawania kształtu własnemu życiu. Jednostka nie ma „barier” w kreowaniu siebie w postaci przynależności klasowej, kapitału kulturowego, poziomu wykształcenia, pochodzenia, które niegdyś determinowały w znaczącym stopniu stylu życia. Autor dookreśla, iż:

w świecie kultury popularnej i konsumpcji jednostka ma możliwość niejako horyzontalnego kreowania swojej tożsamości z dostępnych źródeł kulturowych - może się przemieszczać przez różnorodne płaszczyzny i wybierać komponenty (lub nawet gadżety) do kreacji swojej tożsamości i stylu życia ${ }^{25}$.

W świetle niniejszych rozważań można stwierdzić, iż kultura popularna, konsumpcjonizm, jak również pozostałe trendy współczesności określają

23 Z. Bauman Z., Płynna nowoczesność, przekł. T. Kunz, Kraków 2006, s. 115.

24 Z. Melosik, Kultura popularna i tożsamość młodzieży, s. 170.

25 Tamże, s. 319. 
styl życia współczesnej młodzieży, który staje się coraz bardziej niestabilny, elastyczny, fragmentaryczny, zmienny, a zatem posiada atrybuty tożsame z cechami określającymi współczesną rzeczywistość społeczno-kulturową.

\section{Eklektyczny charakter stylów życia młodzieży we współczesności}

Kategorią, która stanowi niejako istotę stylu życia współczesnej młodzieży jest nie tylko wybór, ale również dobór. Właściwy dobór elementów stylu życia dokonywany był zazwyczaj na podstawie pewnego matrycowego wzoru, zatem wiadome było, iż niniejsze składowe stylu życia musiały zawierać się w pewnym obszarze, co łącznie tworzyło jedną zwartą całość, np. styl życia wielkomiejski. Współcześnie nie istnieją ograniczenia związane z doborem elementów stylu życia - stał się on dowolny, nieograniczony, przez co trudno dokonać charakterystyki czy klasyfikacji stylów życia młodych. Stały się one nieuchwytne, hybrydyczne, niedookreślone.

Zbyszko Melosik podkreśla, iż:

styl życia w społeczeństwie konsumpcji opiera się na zasadzie: „żadnych zasad, jedynie wybory; każdy może być każdym". Konsumpcja nie represjonuje więc tożsamości, lecz dostarcza źródeł fascynacji możliwymi do przybrania tożsamościami (...) Współcześnie dyscyplinowanie tożsamości polega w coraz większym stopniu na narzucaniu „obowiązku bycia sfragmentaryzowanym”. Dyscyplinowanie typu „musisz być taki a taki" zastąpione zostało dyscyplinowaniem odwołującym się do przekonania: „możesz (musisz) być każdym (jednocześnie)”26.

Możliwość lub nawet konieczność „bycia każdym jednocześnie” oznacza permanentną zmienność indywidualnego rysu tożsamościowego (który de facto powinien być ostoją stałości i niezmienności), hybrydyczne łączenie często wręcz wykluczających się zgodnie z tradycyjnym podziałem elementów stylu życia. Znamionuje to ciągłe "dryfowanie po stylach" (Z. Melosik). Owa pozorna dwoistość, powierzchowna sprzeczność, która okazuje się niewykluczająca się wzajemnie to obecnie jedna z cech współczesnej zglobalizowanej rzeczywistości, którą młodzież (i nie tylko) włączyła również do kreacji własnego stylu życia. Jak pisze Z. Melosik:

z perspektywy dawnych standardów taki młody człowiek jest powierzchowny; nie ma głębi i celów życiowych. Żyje zarówno w niewoli nieustannie przekształcającej się pop rzeczywistości, jak i w niewoli nieustannie relatywizującej się własnej pop

${ }^{26}$ Tamże, s. 178. 
tożsamości. Jest to istotą zniewalającej władzy kultury popularnej i zniewalającej jej wolności (...). Przymuszają one do dryfowania i dokonywania tysięcy wyborów, dając w zamian jedynie mozaikową przyjemność i nie zapewniając żadnego oparcia w jakkolwiek rozumianych „podstawach” czy „źródłach”. Tak więc, o ile w przeszłości niewola dotyczyła zamknięcia we własnej przesocjalizowanej tożsamości, o tyle współcześnie polega ona na niemożności wyjścia poza "tożsamościowy dryf" i dryfujący styl życia oraz na braku stałego układu odniesienia27.

W kontekście niniejszych rozważań warto podjąć refleksję na temat istoty stylu życia współczesnego pokolenia młodych, która być może doprowadzi do efektywniejszego zrozumienia, a nie tylko oceniania adolescentów w kontekście ich specyfiki egzystencji w obecnych realiach socjokulturowych. Tego typu analiza zdaje się konieczna w świetle prospektywnej roli, jaką mają do spełnienia w społeczeństwie młodzi.

\section{Zakończenie}

Przedstawione $\mathrm{w}$ niniejszym artykule rozważania teoretyczne na temat stylu życia współczesnej młodzieży ukazują istotność wolności wyboru jako kategorii konstytuującej preferowane style życia. Wynika to ze specyfiki zglobalizowanej rzeczywistości społeczno-kulturowej, która ukierunkowuje jednostkę na kult przyjemności, natychmiastowości, indywidualizm oraz poczucie sprawstwa i autokreacji, co z kolei determinuje przemiany w zakresie stylów życia we współczesności.

Obecnie coraz mniejsze znaczenie $\mathrm{w}$ preferencjach związanych $\mathrm{z}$ własnym stylem życia mają takie czynniki zewnętrzne, jak przynależność społeczna czy kapitał kulturowy. Zostały one zastąpione osobistą decyzją dotyczącą wyboru danego elementu stylu życia, który jest podyktowany aktualnym doznawaniem przyjemności. Teza ta dotyczy w szczególności stylu życia współczesnej młodzieży, ponieważ to ona stanowi grupę społeczną, która najszybciej dostosowuje kształt swojego życia do warunków społeczno-kulturowych, jak również rozumie zachodzące współcześnie przemiany. Wynika to $\mathrm{z}$ faktu, iż istotnym elementem stylu życia młodych jest popkultura, konsumpcjonizm, czas wolny, które to kategorie stanowią główny trzon obecnej rzeczywistości socjokulturowej.

Konkludując, warto podkreślić, iż analiza na temat stylu życia współczesnej młodzieży w kontekście wolności wyboru jako kategorii konstytutywnej powinna stanowić istotny komponent dyskusji na ten temat, ponieważ przybliża do zrozumienia sytuacji obecnego pokolenia młodych.

27 Tamże, s. 448. 


\section{BIBLIOGRAFIA}

Bauman Z., Płynna nowoczesność, przekł. T. Kunz, Wydawnictwo Literackie, Kraków 2006. Bauman Z., Płynne życie, przekł. T. Kunz, Wydawnictwo Literackie, Kraków 2007.

Bourdieu P., Dystynkcja. Społeczna krytyka władzy sadzenia, przekł. P. Biłos, Wydawnictwo Naukowe Scholar, Warszawa 2005.

Bourdieu P., Passeron J-C., Reprodukcja. Elementy teorii systemu nauczania, przekł. E. Neyman, Wydawnictwo Naukowe PWN, Warszawa 2006.

Burszta W.J., Kuligowski W., Sequel. Dalsze przygody kultury w globalnym świecie, Wydawnictwo Literackie Muza, Warszawa 2005.

Giddens A., Nowoczesność i tożsamość. Ja i społeczeństwo w epoce późnej nowoczesności, przekł. A. Szulżycka, Wydawnictwo Naukowe PWN, Warszawa 2006.

Griese H.M., Socjologiczne teorie młodzieży. Wprowadzenie, przekł. J. Dąbrowski, Oficyna Wydawnicza Impuls, Warszawa 1996.

Krajewski M., Kultury kultury popularnej, Wydawnictwo Naukowe UAM, Poznań 2003.

Krzychała S., Ryzyko własnego życia. Indywidualizacja w późnej nowoczesności, Wydawnictwo Naukowe Dolnośląskiej Szkoły Wyższej Edukacji TWP, Wrocław 2007.

Mac-Czarnik L., Procesy poznawcze w planowaniu własnego życia u młodzieży, Wydawnictwo Wyższej Szkoły Pedagogicznej, Rzeszów 2000.

Marody M., Styl życia jako kategoria opisu socjologicznego, [w:] Wartości, praca, zakupy... O stylach życia Polaków, red. M. Falkowska, Centrum Badania Opinii Społecznej, Warszawa 1997.

Mead M., Kultura i tożsamość: studium dystansu międzypokoleniowego, przekł. J. Hołówka, Wydawnictwo Naukowe PWN, Warszawa 2000.

Melosik Z., Kultura popularna $i$ tożsamość młodzieży. W niewoli władzy $i$ wolności, Oficyna Wydawnicza Impuls, Kraków 2013.

Peret-Drążewska P., Współczesna młodzież postrzegana z perspektywy rówieśników. Studium teoretyczno-empiryczne, Wydawnictwo Naukowe UAM, Poznań 2014.

Siciński A., Styl życia, kultura, wybór: szkice, Wydawnictwo IFiS PAN, Warszawa 2002.

Szafraniec K., Młodzi 2011, Kancelaria Prezesa Rady Ministrów, Warszawa 2011.

Tarkowska E., Czas w życiu Polaków, Wydawnictwo IFiS PAN, Warszawa 1992.

Veblen T., Teoria klasy próżniaczej, przekł. J.K. Zagórscy, Państwowe Wydawnictwo Naukowe, Warszawa 1971.

Weber M., Szkice z socjologii religii, przekł. J. Prokupiuk, H. Wandowski, Spółdzielnia Wydawniczo-Handlowa „Książka i Wiedza”, Warszawa 1984.

Wrzesień W., Europejscy poszukiwacze. Impresja na temat wspótczesnego pokolenia polskiej młodzieży, Wydawnictwo Naukowe PWN, Warszawa 2009. 